\title{
Awareness and Incidence of Bullying among Public High School Students in Antique
}

\author{
Janice L. Gonzales ${ }^{1}$ and Dennis V. Madrigal ${ }^{2}$ \\ ${ }^{1}$ Antique National School, Antique, Philippines \\ ${ }^{2}$ University of Negros Occidental-Recoletos, Bacolod City, Philippines
}

\begin{tabular}{l} 
Article history \\
Submitted: 23 October 2020 \\
Revised: 9 November 2020 \\
Accepted: 12 November 2020 \\
\hline Keywords \\
Education \\
Management \\
Bullying \\
Awareness \\
Incidence \\
High School Students \\
Public Schools \\
Descriptive-Correlational \\
Antique
\end{tabular}

and extent of bullying incidence.
Introduction. Bullying is an increasing problem globally, which affects school children over the years. The students who have experienced bullying have a greater risk of psychological distress. Likewise, the incidence of bullying has been increasing despite the efforts of the Philippine government and Department of Education. Moreover, the problem of bullying was even exacerbated by technology resulting in a new form called cyberbullying. Studies also show that students are aware of the different bullying types, yet high bullying incidence still prevails. Hence, the paper describes the level of bullying awareness and the extent of bullying incidence in a public school in Antique during the School Year 2019-2020. The paper also evaluates if a significant difference exists in the level of awareness and the extent of bullying practices when respondents are grouped according to sex, grade level, birth order, living condition, and family monthly income. Furthermore, it also investigates whether a relationship exists between awareness

Methods. The study used a descriptive, comparative, and correlational research approaches. Using a stratified random sampling, 358 junior high school students of a public school in Antique during the school year 2019-2020 participated in the study. On the other hand, a researcher-made questionnaire that underwent validity and reliability testing was used to gather data. Mean, Standard Deviation, Mann Whitney U test, Kruskal-Wallis test, and Spearman Rank Correlation were used to analyze data.

Results. The findings of the study revealed that the level of awareness on bullying of the high school students is generally high regardless of the variables. Furthermore, the extent of bullying in high school students rarely happen. The significant difference in the level of awareness among demographics shows that it exists in terms of sex, grade level, and family monthly income. Females students have a higher level of awareness compared to males. Likewise, the level of awareness among $7^{\text {th }}$ graders is significantly higher than those of $8^{\text {th }}$ graders. Furthermore, respondents coming from a family with high income also possess a higher level of awareness. On the other hand, no significant difference was observed in the level of awareness in terms of living conditions and birth order. On the extent of bullying incidence, a significant difference was only observed in terms of sex. At the same time, other variables show no significant difference. Males have higher bullying incidence compared to females. However, grade level, birth order, living condition, and family monthly income do not appear to predict bullying incidence. In addition, a significant relationship was observed between awareness and bullying incidence.

Conclusion. School-based anti-bullying programs are vital to improving the level of awareness of students on bullying. Thus, by having a clear policy on bullying in school, the students can determine appropriate behavior and bullying consequences. Moreover, the school administrators, guidance counselors, and teachers also play a vital role in improving the level of awareness of junior high school students to reduce bullying incidence in the campus. Furthermore, a higher level of awareness is associated with a lower incidence of bullying. Hence, the school has a big influence on the students in increasing their awareness level and reducing bullying among school-aged youth. 
Practical Value of the Paper. The findings of the study significantly contributed to the dearth of local literature in the level of awareness of students on bullying and the extent of bullying incidence in a public school. Furthermore, the findings served as a basis for an enhanced school-based antibullying program to address the school's bullying concerns that will provide interventions to change student's behavior and create a safer environment where everyone feels secure and motivated.

\section{References}

Cardona, R. S., Reyes, A. S., \& Tangalin, M. M. (2015). The bullying experiences and classroom discipline techniques in an Urban National High School in the Philippines: A basis for an Anti-Bullying Program. American International Journal of Contemporary Research, 5(2), 49-52. Retrieved from http://www.aijcrnet.com/journals/ Vol_5_No_2_April_2015/7.pdf

Chen, L. M. (2015). Self-reported frequency and perceived severity of being bullied among elementary school students. Journal of school health, 85(9), 587-594. doi:https://doi.org/10.1111/josh.12289

Evans, C. B., Fraser, M. W., \& Cotter, K. L. (2014). The effectiveness of school-based bullying prevention programs: A systematic review. Aggression and Violent Behavior, 19(5), 532-544. doi:https://doi.org/10.1016/j.avb.2014.07.004

Fu, Q., Land, K. C., \& Lamb, V. L. (2013). Bullying victimization, socioeconomic status, and behavioral characteristics of 12th graders in the United States, 1989 to 2009: repetitive trends and persistent risk differentials. Child Indicators Research, 6(1), 1-21. doi:https://doi.org/10.1007/s12187-012-9152-8

Jaradat, A. K. M. (2017). Gender differences in bullying and victimization among early adolescents in Jordan. PEOPLE: International Journal of Social Sciences, 3(3). doi:https://dx.doi.org/10.20319/pijss.2017.33.440451

Laus, Magnolia A. "A Profile of Bullying, Peer Aggression, and Victimization in Philippine Junior High School." Journal of Society \& Technology 6 (2016): 22-36.

Modecki, K. L., Minchin, J., Harbaugh, A. G., Guerra, N. G., \& Runions, K. C. (2014). Bullying prevalence across contexts: A meta-analysis measuring cyber and traditional bullying. Journal of Adolescent Health, 55(5), 602-611.

Gusho, L. P. (2015). Relationship between Physical Bullying and Age in Albanian Teenagers. European Journal of Social Science Education and Research, 2(3), 166-171.

Sanapo, M. S. (2017). When kids hurt other kids: Bullying in Philippine schools. Psychology, 8(14), 2469-2484. doi:https://doi.org/10.4236/psych.2017.814156

Smith, P. K. (2016). Bullying: Definition, types, causes, consequences, and intervention. Social and Personality Psychology Compass, 10(9), 519-532. doi:10.1111/spc3.12266

\section{Correspondence:}

Janice L. Gonzales [janice.gonzales003@deped.gov.ph]

https://orcid.org/0000-0002-9869-8421 